\title{
ANALISIS MISKONSEPSI TENTANG KEMAGNETAN PADA SISWA MTs ISHLAHUL MUSLIMIN SENTELUK KELAS IX TAHUN AJARAN 2018/2019
}

\author{
Nur'aini $^{1 *}$, Lalu A. Didik², Bahtiar ${ }^{2}$ \\ Mahasiswa $^{1}$, Dosen ${ }^{2}$ Program Studi Tadris Fisika Fakultas Tarbiyah dan Keguruan, Universitas \\ Islam Negeri Mataram, NTB, Indonesia \\ Korespondensi: nurainifisika@gmail.com
}

\begin{abstract}
Abstrak: Penelitian ini bertujuan untuk mengetahui: (1) pemahaman konsep siswa terhadap magnet, (2) miskonsepsi siswa yang terjadi pada konsep magnet, (3) menganalisis miskonsepsi siswa yang terjadi pada materi magnet. Jenis penelitian yang digunakan adalah penelitian deskriptif dengan menggunakan metode deskriptif kualitatif yang di dalamnya menjelaskan hasil dari suatu penelitian. Hasil analisis data menunjukkan bahwa rata-rata persentase miskonsepsi sebagai berikut: pada paham konsep sebesar 14,38\%, miskonsepsi sebesar 25,17\%, miskonsepsi (false positif) sebesar 15,21\%, miskonsepsi (false negative) sebesar 11,82\%, menebak sebesar $4,22 \%$ dan untuk yang tidak paham konsep sebesar 28,43\%. Siswa masih banyak mengalami miskonsepsi pada materi, pengertian magnet, jenis-jenis magnet, interaksi benda ketika di dekatkan dengan magnet, pembuatan magnet, sifat-sifat magnet, garis gaya dan medan magnet, elektromagnetik, dan gaya Lorentz.
\end{abstract}

Kata Kunci: Miskonsepsi, Magnet.

\section{MISCONCEPTION ANALYSIS ABOUT MAGNETISM AMONG MTS STUDENTS OF ISHLAHUL MUSLIMIN SENTELUK CLASS IX IN THE 2018/2019 SCHOOL YEARS}

Abstract: the aimed of this research is to know: (1) comprehension of students' concept toword magnet, (2) students' misconception which occurred in concept of magnet, (3) analyzing students' misconception which occurred in the material of magnet. The research type of this study is descriptive research that used descriptive qualitative in which this research explained the result of this research. The result of the data analysis shown that the mean of misconception as follow: in understanding the concept by 14,38\%, misconceptions by 25,17\%, misconceptions (false positive) by 15,21\%, misconceptions (false negative) by 11,82\%, guessing by 4,22\% and for those not understanding the concept by 28,43\%. Students still experience a lot of misconceptions on the material understanding of magnets, types of magnets, interactions of objects when they are close to magnets, making magnets, magnetic properties, magnetic lines and magnetic fields, electromagnetic, and Lorentz forces.

Keywords: misconceptions, magnets.

\section{PENDAHULUAN}

Fisika adalah salah satu mata pelajaran yang begitu banyak menuntut intelektualitas yang begitu tinggi sehingga sebagian besar dari peserta didik banyak yang mengalami kesulitan dalam 
belajar. Akibatnya banyak menimbulkan kesalahan di dalam proses belajar mengajar fisika ketika sedang berlangsung.

Kualitas pendidikan sangat bergantung pada bagaimana proses belajar itu berlangsung. Menurut Permendikbud nomer 81 A tahun 2013 tentang implementasi kurikulum menyatakan bahwa proses belajar atau kegiatan pembelajaran merupakan proses pendidikan yang memberikan kesempatan kepada peserta didik untuk mengembangkan potensi mereka menjadi kamampuan yang semakin lama semakin meningkat dalam sikap, pengetahuan, dan keterampilan yang diperlukan dirinya untuk hidup dan untuk bermasyarakat, berbangsa, serta berkontribusi pada kesejahteraan hidup umat islam.

Berdasarkan hasil nilai try out yang telah dilakukan di MTs Ishlahul Muslimin Senteluk didapatkan niai untuk mata pelajaran IPA yaitu dengan nilai rata-rata 4,20, dari nilai yang telah didapatkan pada mata pelajaran IPA dapat dikatakan rendah. hal ini menunjukkan adanya kesulitan yang dialami oleh siswa sehingga nilai yang mereka peroleh tidak memuaskan.

Menurut (Yolanda, 2017) Miskonsepsi di dalam pembelajaran fisika sering sekali terjadi sehingga hal ini bisa menjadi penghambat siswa dalam memahami konsep yang akan di pelajari, sehingga menimbulkan kesulitan dan kesalah di dalam belajar fisika.

Miskonsepsi merupakan suatu konsep dimana konsep ini tidak sesuai dengan konsepsi yang telah diakui oleh para ahli. Banyak sekali yang mempengaruhi terjadinya miskonsepsi salah satunya yaitu bisa berasal dari buku ajar yang di jadikan panduan oleh pendidik maupun peserta didik. Faktor utama yang menyebabkan terjadinya miskonsepsi dalam fisika yaitu berasal dari siswa, pendidik, cara mengajar dan buku ajar (Khoiri, Wijaya, \& Kusumawati, 2017).

\section{METODE}

Penelitian ini dilaksanakan di MTs Ishlahul Muslimin Senteluk Lombok Barat. Penelitian ini merupakan penelitian deskriptif dengan menggunakan metode deskriptif kualitatif. Teknik pengumpulan data melalui tes yaitu dengan menggunakan instrument diagnostik berupa three tier test yang dilengkapi dengan tingkat keyakinan. Data hasil tes diagnostik kemudian dinyatakan dalam bentuk persentase kategori konsepsi siswa. Teknik pengambilan sampel dalam penelitian ini adalah purposive sampling, sampel penelitian ini adalah siswa yang sudah mempelajari materi magnet dengan jumlah 55 siswa. Terdapat beberapa keputusan dalam three tier test. Berikut adalah tabel keputusan three tier test.

Table 1. Kategori Jawaban Three Tier Test

\begin{tabular}{c|c|c|c}
\hline $\begin{array}{c}\text { Tingkat } \\
\text { pertama }\end{array}$ & $\begin{array}{c}\text { Tingkat } \\
\text { kedua }\end{array}$ & $\begin{array}{c}\text { Tingkat } \\
\text { ketiga }\end{array}$ & Kategori \\
\hline Benar & Benar & Yakin & Paham konsep \\
Benar & Salah & Yakin & Miskonsepsi (false positive) \\
Salah & Benar & Yakin & Miskonsepsi (false negative)
\end{tabular}




\begin{tabular}{cccc} 
Benar & Benar & Tidak yakin & Menebak, kurang percaya diri \\
Benar & Salah & Tidak yakin & Tidak paham konsep \\
Salah & Salah & Yakin & Miskonsepsi \\
Salah & Benar & Tidak yakin & Tidak paham konsep \\
Salah & Salah & Tidak yakin & Tidak paham konsep \\
\hline
\end{tabular}

Pada penelitian ini ada beberapa tahapan penelitian yang telah dilakukan yaitu: tahap pendahuluan, tahap penyusunan instrumen tes penelitian, tahap mengumpulkan data, tahap analisis data, dan yang terahir berupa kesimpulan.

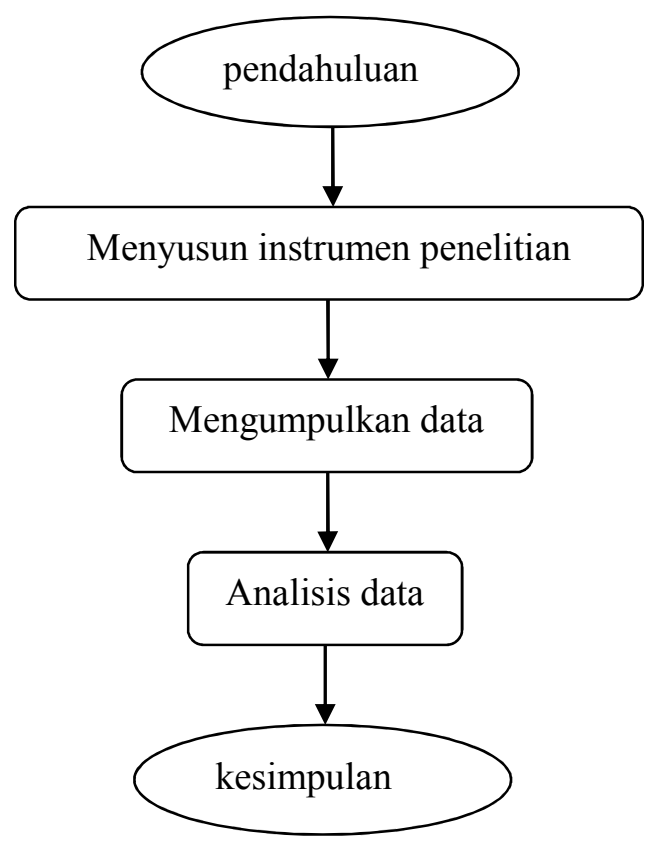

Gambar 1. Prosedur Penelitian

\section{HASIL DAN PEMBAHASAN}

\section{Hasil}

Berdasarkan hasil penelitian yang telah dilakukan yang berkaitan tentang miskonsepsi yang terjadi pada siswa pada materi magnet diperoleh hasil persentase miskonsepsi setiap butir soal adalah sebagai berikut.

\section{Tabel 2. Persentasi Miskonsepsi}




\begin{tabular}{|c|c|c|c|c|c|c|}
\hline No & $\begin{array}{l}\text { Paham } \\
\text { konsep }\end{array}$ & Miskonsepsi & $\begin{array}{l}\text { Miskonsepsi } \\
\text { (false positif) }\end{array}$ & $\begin{array}{c}\text { Miskonsepsi } \\
\text { (false } \\
\text { negative) }\end{array}$ & Menebak & $\begin{array}{l}\text { Tidak } \\
\text { paham } \\
\text { konsep }\end{array}$ \\
\hline 1 & $20 \%$ & $34,5 \%$ & $10,91 \%$ & $14,54 \%$ & $0 \%$ & $20 \%$ \\
\hline 2 & $27,27 \%$ & $15,55 \%$ & $10,91 \%$ & $16,36 \%$ & $12,73 \%$ & $18,18 \%$ \\
\hline 3 & $20 \%$ & $25,45 \%$ & $12,73 \%$ & $9,09 \%$ & $3,64 \%$ & $20,09 \%$ \\
\hline 4 & $12,73 \%$ & $30,91 \%$ & $20 \%$ & $9,09 \%$ & $1,82 \%$ & $25,45 \%$ \\
\hline 5 & $36,36 \%$ & $14,55 \%$ & $14,55 \%$ & $5,45 \%$ & $12,73 \%$ & $16,36 \%$ \\
\hline 6 & $7,27 \%$ & $41,82 \%$ & $12,73 \%$ & $7,27 \%$ & $1,82 \%$ & $29,09 \%$ \\
\hline 7 & $23,64 \%$ & $30,91 \%$ & $10,91 \%$ & $12,73 \%$ & $0 \%$ & $21,82 \%$ \\
\hline 8 & $9,09 \%$ & $32,73 \%$ & $14,55 \%$ & $12,73 \%$ & $3,64 \%$ & $27,27 \%$ \\
\hline 9 & $12,73 \%$ & $23,64 \%$ & $14,55 \%$ & $10,91 \%$ & $7,27 \%$ & $30,91 \%$ \\
\hline 10 & $32,73 \%$ & $14,55 \%$ & $10,91 \%$ & $14,55 \%$ & $9,09 \%$ & $18,18 \%$ \\
\hline 11 & $16,36 \%$ & $25,45 \%$ & $10,91 \%$ & $12,73 \%$ & $7,27 \%$ & $27,27 \%$ \\
\hline 12 & $12,73 \%$ & $18,18 \%$ & $23,64 \%$ & $9,095 \%$ & $3,64 \%$ & $32,73 \%$ \\
\hline 13 & $12,73 \%$ & $23,64 \%$ & $16,36 \%$ & $9,09 \%$ & $0 \%$ & $38,18 \%$ \\
\hline 14 & $9,09 \%$ & $27,27 \%$ & $21,82 \%$ & $10,91 \%$ & $1,82 \%$ & $29,09 \%$ \\
\hline 15 & $7,27 \%$ & $25,45 \%$ & $14,55 \%$ & $12,73 \%$ & $7,27 \%$ & $32,73 \%$ \\
\hline 16 & $12,73 \%$ & $20 \%$ & $21,82 \%$ & $16,36 \%$ & $1,82 \%$ & $27,27 \%$ \\
\hline 17 & $7,27 \%$ & $20,09 \%$ & $14,55 \%$ & $7,27 \%$ & $3,64 \%$ & $38,18 \%$ \\
\hline 18 & $7,27 \%$ & $21,82 \%$ & $18,18 \%$ & $14,55 \%$ & $3,64 \%$ & $34,55 \%$ \\
\hline 19 & $10,91 \%$ & $20 \%$ & $10,91 \%$ & $16,36 \%$ & $1,82 \%$ & $40 \%$ \\
\hline 20 & $5,45 \%$ & $29,09 \%$ & $16,36 \%$ & $10,91 \%$ & $3,64 \%$ & $34,55 \%$ \\
\hline 21 & $7,27 \%$ & $34,54 \%$ & $12,73 \%$ & $9,09 \%$ & $5,45 \%$ & $30,91 \%$ \\
\hline 22 & $5,45 \%$ & $23,64 \%$ & $20 \%$ & $18,18 \%$ & $0 \%$ & $32,73 \%$ \\
\hline $\begin{array}{l}\text { Rata- } \\
\text { Rata }\end{array}$ & $14.38 \%$ & $25.17 \%$ & $15.21 \%$ & $11.82 \%$ & $4.22 \%$ & $28.43 \%$ \\
\hline
\end{tabular}




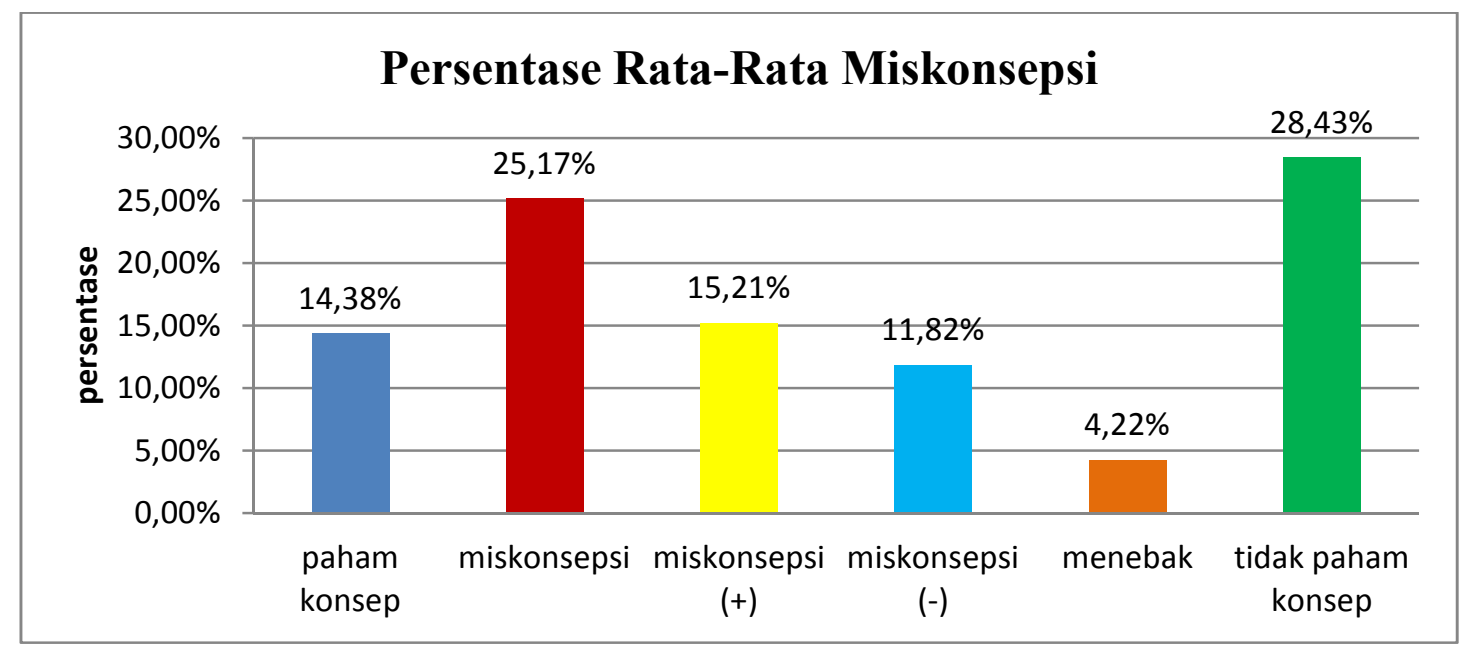

Gambar 2. Persentase Rata-Rata Miskonsepsi

\section{Pembahasan}

Berdasarkan hasil tes yang telah dilaksanakan dengan menggunakan instrument tes diagnostic dengan format three tier diagnostic test ternyata dapat mendeteksi adanya miskonsepsi yang telah di alami oleh peserta didik yaitu pada materi magnet.

Berdasarkan pada grafik 1. diatas dapat dilihat bahwa persentase rata-rata miskonsepsi yang paling tinggi berada pada tidak paham konsep yaitu sebesar 28,43\%, sedangkan yang masih mengalami miskonsepsi sebanyak 25,17\%. Ini menandakan bahwa masih banyak siswa yang mengalami miskonsepsi pada materi magnet sehingga miskonsepsi yang dihadapi oleh siswa ini perlu untuk di perbaiki agar siswa mendapatkan konsep yang benar.

Berdasarkan soal nomer 1 yaitu mengenai pengertian tentang magnet disini siswa masih mengalami miskonsepsi. Berdasarkan pada grafik diatas miskonsepsi yang terjadi pada siswa sebanyak 34,5\% dengan siswa sebanyak 19 siswa, yang memahami konsep sebesar 20\% sebanyak 11 siswa, kemudian untuk yang false positif sebanyak 10,91\% sebanyak 6 siswa, kemudian yang false negative sebanyak 14,54\% dengan jumlah siswa sebanyak 8 , yang menebak $0 \%$ dan yang tidak paham konsep sebanyak 20\% dengan jumlah siswa 11 orang. Siswa masih beranggapan bahwa magnet merupakan besi yang dapat menarik logam, padahal konsep yang benar adalah magnet merupakan sejenis logam yang dapat menarik benda-benda logam tertentu.

Berdasarkan soal nomer 2 mengenai jenis-jenis benda magnetik disini siswa masih mengalami miskonsepsi. Miskonsepsi yang terjadi pada siswa sebanyak $15,55 \%$ dengan banyaknya siswa 8 , yang memahami konsep sebesar 27,27\% sebanyak 15 siswa, kemudian untuk yang false positif sebanyak 10,91\% sebanyak 6 siswa, kemudian yang false negative sebanyak $16,36 \%$ dengan jumlah siswa sebanyak 9, yang menebak 12,73\% sebanyak 7 siswa dan yang tidak paham konsep sebanyak18,18\% dengan jumlah siswa 10 orang. Pada konsep ini siswa masih keliru dalam membedakan antara bahan feromagnetik, paramagnetik dan diamagnetik. Sebagian mereka mengatakan feromagnetik adalah benda yang tidak dapat di tarik dengan kuat oleh magnet dan sebagian juga dari mereka ada yang menjawab dengan konsep yang benar. Padahal konsep yang sebenarnya adalah feromagnetik adalah bahan yang dapat di tarik dengan 
cukup kuat oleh magnet. Sedangkan untuk paramagnetik adalah bahan yang hanya ditarik sedikit oleh magnet kuat. Diamagnetik adalah bahan yang ditolak oleh magnet kuat.

Berdasarkan soal yang ke 3 yaitu mengenai interaksi benda jika didekatkan dengan magnet. Pada konsep ini siswa masih banyak mengalami miskonsepsi sebanyak $25,45 \%$ dengan banyaknya siswa 14, yang memahami konsep sebesar 20\% sebanyak 11 siswa, kemudian untuk yang false positif sebanyak 12,73\% sebanyak 7 siswa, kemudian yang false negative sebanyak 9,09\% dengan jumlah siswa sebanyak 5, yang menebak 3,64\% sebanyak 2 siswa dan yang tidak paham konsep sebanyak 20,09\% dengan jumlah siswa 16 orang. Sebagian siswa memberikan alasan pines dan emas dapat ditarik oleh magnet karena memiliki kadara besi, aluminium dan emas dapat di tarik oleh magnet karena semua benda yang terbuat dari logam dapat di tarik oleh magnet. Setelah di analisis ternyata siswa masih mengalami miskonsepsi konsep yang sebenarnya adalah tidak semua logam dapat ditarik oleh magnet dan salah satu logam yang tidak bisa di tarik oleh magnet adalah emas karena emas termasuk dalam golongan diamagnetik. Pada penelitian (Silviani, Mulyani, \& Kurniawan, 2017) ditemukan miskonsepsi pada konsep semua logam dapat ditarik magnet.

Berdasarkan soal nomer 4, 6 14, 15, 16, 17, dan 22 yaitu miskonsepsi tentang pembuatan magnet dan penentuan kutub magnet. Pada soal nomer 6 yaitu mengenai benda yang bukan magnet dapat di jadikan sebagai magnet. Sebagian siswa menjawab benda yang dapat di jadikan sebagai magnet adalah suatu benda yang dapat di tarik oleh magnet, karena mereka beranggapan bahwa benda yang dapat di tarik oleh magnet adalah benda yang pastinya mengandung logam yang akan di tarik oleh magnet. Selain itu mereka juga beranggapan bahwa semua benda yang bentuknya padat dapat dijadikan magnet. Dari berbagai alasan yang telah dipaparkan oleh siswa menunjukkan masih ada yang mengalami miskonsepsi tentang benda yang bukan magnet dapat dijadikan sebagai magnet padahal konsep yang benar yaitu benda yang dapat di jadikan sebagai magnet merupakan benda yang dapat di tarik dengan kuat oleh magnet seperti pada jenis benda feromagnetik yang dapat di jadikan sebagai magnet dengan cara menggosokkan benda tersebut ke magnet yang permanen. Sedangkan untuk menentukan letak kutub magnet dapat dilakukan dengan menggunakan aturan tangan kanan. Ketika menggunakan aturan tangan kanan siswa masih keliru dalam menentukan arah, sebagian mereka mengatakan bahwa ibu jari menunjukkan arah arus sedangkan keempat jari menunjukkan arah kutub. Konsep yang benar adalah ketika menggunakan aturan tangan kanan ibu jari menunjukkan arah kutub sedangkan untuk keempat jari menunjukkan arah arus listrik

Pada penelitian (Setyaningsih, Harijanto, \& Prastowo, 2018) ditemukan miskonsepsi pada konsep yang sama, dalam penelitiannya siswa masih beranggapan bahwa saat sebuah magnet didekatkan pada suatu logam maka magnet elementer pada logam akan terinduksi sehingga letak magnet elementer pada logan akan mengarah pada satu arah dan teratur.

Berdasarkan soal nomer 5,7, dan 8 mengenai konsep sifat-sifat magnet, pada soal ini jawaban alasan yang di berikan bervariasi. Miskonsepsi yang paling banyak terjadi pada soal nomer 8 yaitu sebanyak 32,73\% dengan jumlah siswa sebanyak 18 siswa tentang magnet yang didekatkan pada jarum. Alasan yang di berikan oleh siswa bermacam-macam, siswa beralasan jarum akan menempel pada salah satu ujung magnet karena mereka beralasan bahwa magnet hanya dapat menarik benda menggunakan salah satu ujungnya dan ujungnya yang satu akan menolak benda. Sebagian siswa juga menjawab jarum akan menempel pada semua permukaan magnet karena magnet akan menarik semua benda yang jenisnya logam dan besi, sebagian juga 
menjawab jarum yang didekatkan dengan magnet akan menempel pada bagian kedua ujung magnet karena gaya tarik magnet paling besar terjadi pada bagian magnet sesuai dengan konsep yang sebenarnya. Sedangkan yang memahami konsep sebesar 9,09\% sebanyak 5 siswa, kemudian untuk yang false positif sebanyak 14,55\% sebanyak 8 siswa, kemudian yang false negative sebanyak $12,73 \%$ dengan jumlah siswa sebanyak 7 , yang menebak $3,64 \%$ sebanyak 2 siswa dan yang tidak paham konsep sebanyak 27,27\% dengan jumlah siswa 15 orang.

Berdasarkan pada soal nomer 9 dan 10 tentang garis gaya dan medan magnet. Siswa beranggapan bahwa rapat garis gaya magnet tidak dapat mempengaruhi medan magnet karena tidak adanya arus listrik yang teralir. Konsep yang di berikan oleh siswa jelas konsep yang tidak tepat konsep yang benar adalah semakin rapat garis gaya magnet, maka akan menimbulkan medan magnet yang semakin kuat.

Berdasarkan soal nomer 11, 18,19, 20, dan 21 siswa masih mengalami miskonsepsi pada konsep elektromagnetik yaitu mengenai penambahan jumlah lilitan, siswa yang mengalami miskonsepsi sebanyak 25,45\% dengan jumlah siswa 14. Mereka menganggap bahwa semakin banyak batrai yang di tambahkan akan semakin terbagi arus listrik yang di miliki sehingga gaya tarikannya akan semakin lemah konsep ini tentunya konsep yang salah. Konsep yang benar adalah electromagnet dapat di perkuat dengan menambahkan jumlah lilitannya pada kumparan, dapat dilakukan dengan penambahan baterai yang lebih banyak dan menggunakan kawat yang penampangnya lebih besar.

Berdasarkan soal 12 dan 13 digunakan untuk mengetahui miskonsepsi yang terjadi pada konsep gaya Lorentz. Sebagian besar siswa menjawab gaya Lorentz adalah gaya tarik menarik antar magnet karena ketika magnet mengalami gaya tarik menarik maka magnet akan menimbulkan gaya Lorentz. Konsep yang di berikan oleh siswa tentunya tidak tepat karena gaya Lorentz merupakan suatu gaya yang ditimbulkan oleh wakat yang berarus dalam medan magnet karena gaya Lorentz akan terjadi apabila ada kawat yang memiliki arus listrik dan berada di dalam medan magnet.

(Ulfah, \& Fitriyani). Sebab khusus terjadinya miskonsepsi yang berasal dalam diri siswa dapat dikelompokkan dalam beberapa kelompok yaitu sebagai berikut:

1. Pemikiran asosiasi siswa, dalam penggunaan istilah yang diberikan oleh guru diartikan (diasosiasikan) lain oleh siswa.

2. Intuasi yang dimiliki oleh siswa salah.

3. Kemampuan siswa, siswa yang kurang mampu dalam memahami atau mempelajari fisika sering kali menghadapi kesulitan di dalam memahami konsep fisika.

4. Minat belajar siswa, siswa yang memiliki minat yang besar terhadap fisika akan cenderung memiliki miskonsepsi lebih rendah dari yang memiliki minat belajar yang lebih sedikit terdapat pelajaran fisika.

\section{PENUTUP}

Berdasarkan hasil analisis data dan pembahasan dapat diambil kesimpulan bahwa masih banyak siswa yang mengalami miskonsepsi pada materi magnet. Siswa masih mengalami miskonsepsi pada konsep pengertian magnet, jenis-jenis magnet, interaksi benda ketika 
didekatkan dengan magnet, pembuatan magnet, sifat-sifat magnet, garis gaya dan medan magnet, elektromagnetik, gaya Lorentz.

\section{DAFTAR PUSTAKA}

Permendikbud 2013 No 81 A, implementasi kurikulum.

Yaspin Yolanda. (2017). Remediasi miskonsepsi kinematika gerak lurus dengan pendekatan STAD. Science and physicseducation journal (SPEJ).1(1).

Hasan Khoiri, Andika Kusuma Wijaya, Intan Kusumawati. (2017). Identifikasi miskonsepsi buku ajar fisika SMA kelas X pada pokok bahasan kinematika gerak lurus. Jurnal Ilmu Pendidikan Fisika, 2(2).

Eri Setyaningsih. (2018). Identifikasi miskonsepsi materi medan magnet menggunakan three tier test pada siswa kelas XII SMA di Jember. Seminar nasional pendidikan fisika., 3(1).

Siti Ulfah, Harina Fitriyani. Certainty Of Response Index (Cri): Miskonsepsi Siswa Smp Pada Materi Pecahan. Seminar Nasional Pendidikan, Sains dan Teknologi.

Reny Silviani, Riski Muliyani, Yudi Kurniawan. (2017). Penerapan three tier untuk identifikasi kuantitas siswa yang miskonsepsi pada materi magnet. Jurnal Ilmu Pendidikan Fisika. 2(1). 